\title{
EFFECTS OF EARLY SKIP DAY FEEDING ON GROWTH PERFORMANCE AND BODY COMPOSITION IN BROILERS
}

\author{
U. Santoso, K. Tanaka ${ }^{1}$ and S. Ohtani \\ Science of Biological Production, The United Graduate School of Agricultural Science \\ and Department of Animal Science and Technology, Faculty of Agriculture \\ Gifu University, Gifu 501-11, Japan
}

\begin{abstract}
Summary
Four hundred and eighty broiler chicks of both sexes were obtained from commercial hatchery (Hubbard) and raised on floor pens. All chicks were allowed free access to food from 0 to 7 and 20 to 56 days of age. At 7 days of age, all broilers were weighed individually, and divided into five groups as follows: 1 . feed ad libitum as the control; 2. allowed free access to food 3 days and starved 1 day $(3 \times 1)$; 3 . allowed free access to food 2 days and starved 1 day $(2 \times 1)$; 4. allowed free access to food 1 day and starved 1 days $(1 \times 1)$ and; 5. allowed free access to food 2 days and starved 2 days $(2 \times 2)$. Broilers were restricted for 12 days $(\mathrm{d} 7$ through 17$)$ of a 56-day trial. Broilers were fed a commercial starter diet (crude protein $23.8 \%$ and ME 3,070 kcal $/ \mathrm{kg}$ ) for 21 days, and commercial finisher diet (crude protein $20 \%$ and ME 3,160 kcal $/ \mathrm{kg}$ ) from 22 to 56 days of age. Although there was compensatory growth in some groups, (the $1 \times 1$ female group, and the $3 \times$ 1 and $2 \times 1$ male grous), its level was not sufficient to achieve normal body weight at market age. There was sexual dimorphism for accelerated growth as well as differences in the ability to achieve a complete compensation of growth to the weight, feed conversion ratio, and body composition of ad libitum chicks. Early feed restriction could be used to reduce production cost because of the lower fed conversion ratio, mortality rate and the amount of starter diet consumed by broilers. The response of chicks to early feed restriction might depend on the degree of feed restriction, the method of feed restriction, duration of feed restriction, and sexes.
\end{abstract}

(Key Words : Compensatory Growth, Skip Day Feeding, Body Fat, Triglyceride)

\section{Introduction}

Various feed restriction methods were used in broilers for reducing body fat and/or abdominal fat without loss in performance characteristic with better feed efficiency (Plavnik and Hurwitz, 1985, 1988, 1990, 1991; Santoso et al., 1993; Plavnik et al., 1986; Rosebrough et al., 1986). Previous observation in our laboratory showed that compensatory growth was occurred when broilers were fed various feed intake regimes (Santoso et al., 1993). However, body fat content was reduced only in female chicks fed $55 \%$ or $45 \%$ feeding with abdominal fat weight similar to the ad libitum chicks. The degree of feed restriction, duration, sex and age influence the occurrence of compensatory growth (Plavnik and

${ }^{1}$ Address reprint requests to Dr. K. Tanaka, Department of Animal Science and Technology, Faculty of Agriculture. Gifu University, Gifu 501-11, Japan.

Received April 19, 1993

Accepted July 6, 1993
Hurwitz, 1988).

Restricted chicks could reach body weight similar to the ad libitum chicks at 39 days of age when chicks were fed free access to feed and starved on alternate day for 6 days (Balley et al., 1992). Furthermore, restriction for more than 6 days improved feed efficiency with no compensatory growth. Some reports (Washburn and Bondari, 1978; Yu et al., 1990) failed to show compensatory growth. No compensatory growth may be due to the longer period of feed restriction (Plavnik et al., 1986) and its severity was not sufficient (Wilson and Osbron, 1960). Our previous study (Santoso et al., 1993) showed that compensatory growth was occurred when broiler chicks were feed-restricted for 10 days from 7 to 17 days of age. However, the use of this method in commercial practice may be limited bacause it spends much time. Therefore, the method applied in this experiment was designed to be similar to the previous method in the degree of restriction using skip day feeding programs. 


\section{Materials and Methods}

Animal and diets

Four hundred and eighty broiler chicks of both sexes were obtained from a commercial hatchery and raised on floor pens. All chicks were allowed free access to food from 0 to 7 and 20 to 56 days of age. Water was made available at all times. At 7 days of age, all chicks were weighed and divided into 5 groups of 48 chicks each as follows: 1) fed ad libitum as the control; 2) allowed free access to food 3 days and starved 1 day $(3 \times 1)$ (the degree of feed intake was assumed $75 \%$; 3) allowed free access to food 2 days and starved 1 day $(2 \times 1)$ (the degree of feed intake was assumed $(66 \%) ; 4)$ allowed free access to food 1 day and starved 1 days $(1 \times 1)$ (the degree of feed intake was assumed $50 \%) ; 5)$ allowed free access to food 2 days and starved 2 days $(2 \times 2)$ (the degree of feed intake was assumed 50\%). Birds were restricted for 12 days (d 7 through 19) of a 56-day trial. Each treatment group was represented by one replicate floor pen. Body weight was obtained weekly, and feed intake was determined daily.

Chicks were fed a commercial starter diet (crude protein: $23.8 \%$, crude fat: $5.8 \%$, crude fiber: $2.5 \%$, crude ash: $5.3 \%$ and Metabolizable Energy (ME): $3,070 \mathrm{kcal} / \mathrm{kg}$ ) for 21 days, and commercial finisher diet (crude protein: $20 \%$, crude fat: $6.8 \%$, crude fiber: $2.6 \%$, crude ash: $5.0 \%$ and ME: $3,160 \mathrm{kcal} / \mathrm{kg}$ ) from 22 to 56 days of age.

\section{General procedure}

At 21 and 56 days of age, eight broilers were selected from each treatment group and then sacrified one by one by decapitation. The liver and abdominal fat were immediately removed and weighed. One part of liver of female chicks were placed in an ice-cold saline to determine the activities of lipogenic enzymes, and another part of those livers were frozen and stored at $-30^{\circ} \mathrm{C}$ prior to analysis of various lipid fractions. The various lipid fractions were separated by thin layer chromatography on silica gel chromarod using hexane/diethyl ether/formic acid (85:15: 0.15 ) as developing solvent, and quantitated by IATROSCAN (Tanaka et al., 1979). At 56 days of age, carcasses as previously described (Santoso et al., 1993) were also obtained. After the car- casses were cut, carcasses including abdominal fat were frozen and stored in a sealed plastic bag at $-30^{\circ} \mathrm{C}$ prior to subsequent analysis. The frozen carcasses were minced as previously described (Santoso et al., 1993). Fat, moisture and protein contents of carcasses were determined by the method of AOAC (1980).

\section{Preparation of liver homogenates}

Livers were homogenized in $0.25 \mathrm{M}$ sucrose solution containing $1 \mathrm{mM}$ ethylene diamine tetra acetate $-\mathrm{Na}_{2}$ (EDTA- $\mathrm{Na}_{2}$ ), after which the homogenates were centrifuged at $600 \mathrm{~g}$ at $4^{\circ} \mathrm{C}$ for 15 minutes. The supernatants were recentrifuged at $105,000 \mathrm{~g}$ at $4^{\circ} \mathrm{C}$ for 60 minutes and the resulting clear supernatants (cytosolic fraction) were used for assaying lipogenic enzymes.

\section{Enzyme assay}

Acetyl-CoA carboxylase was assayed by $\mathrm{H}^{14}$ $\mathrm{CO}_{3}^{-}$-fixation method (Qureshi et al., 1980). Fatty acid synthetase was assayed by $1{ }^{14} \mathrm{C}$-acetyl-CoA incorporation method (Hsu et al., 1965). The protein content of solutions used for enzyme assay was determined by the method of Lowry et al. (1951) using albumin as the standard. Enzyme activities are expressed as nanomole of substrate converted to product per minute per $\mathrm{mg}$ protein at $37^{\circ} \mathrm{C}$.

\section{Statistical analyses}

All data were statistically analyzed using the one-way or two-way analysis of variance (Yoshida, 1975). Significant differences between treatment were determined by Duncan's multiple range test (Duncan, 1955).

\section{Results and Discussion}

Effect of early skip day feeding on growth performance of broilers are shown in table 1 . As expected, body weights were lighter in the feed-skipped chicks after the end of skip day feeding programs. In general, the body weight gains were lower during skip day feeding programs in feed-skipped chicks, and during refeeding those body weight gains were similar to control chicks except for $1 \times 1$ (in females), $3 \times 1$, and $2 \times 1$ (in males) treatment groups which exhibited compensatory growth but this compensatory growth was not sufficient to recover 
EARLY SKIP DAY FEEDING AND GROWTH

TABLE 1. EFFECT OF EARLY SKIP DAY FEEDING ON PERFORMANCE OF BROILERS

\begin{tabular}{|c|c|c|c|c|c|c|c|}
\hline \multirow{2}{*}{$\begin{array}{c}\text { Age } \\
\text { (days) }\end{array}$} & \multicolumn{5}{|c|}{ Female $^{1}$} & \multicolumn{2}{|c|}{ Male $^{1}$} \\
\hline & Control & $3 \times 1$ & $2 \times 1$ & $1 \times 1$ & $2 \times 2$ & Control & $3 \times 1$ \\
\hline \multicolumn{8}{|c|}{ Body weight } \\
\hline 7 & $0.14^{2}$ & 0.14 & 0.14 & 0.14 & 0.14 & 0.14 & 0.14 \\
\hline 14 & $0.36^{\mathrm{e}}$ & $0.33^{\mathrm{d}}$ & $0.31^{\mathrm{c}}$ & $0.28^{\mathrm{b}}$ & $0.21^{\mathrm{a}}$ & $0.38^{\mathrm{e}}$ & $0.34^{\mathrm{d}}$ \\
\hline 19 & $0.60^{\mathrm{e}}$ & $0.46^{\mathrm{d}}$ & $0.43^{\mathrm{c}}$ & $0.38^{\mathrm{b}}$ & $0.26^{\mathrm{a}}$ & $0.65^{\mathrm{e}}$ & $0.48^{\mathrm{d}}$ \\
\hline 21 & $0.69^{d}$ & $0.56^{\mathrm{c}}$ & $0.55^{\mathrm{c}}$ & $0.48^{b}$ & $0.40^{\mathrm{a}}$ & $0.76^{\mathrm{e}}$ & $0.60^{\mathrm{d}}$ \\
\hline 28 & $1.14^{\mathrm{d}}$ & $1.00^{\mathrm{c}}$ & $0.98^{\mathrm{c}}$ & $0.92^{\mathrm{b}}$ & $0.78^{\mathrm{a}}$ & $1.33^{\mathrm{e}}$ & $1.18^{\mathrm{d}}$ \\
\hline 35 & $1.62^{\mathrm{d}}$ & $1.47^{\mathrm{c}}$ & $1.43^{\mathrm{bc}}$ & $1.39^{\mathrm{b}}$ & $1.25^{\mathrm{a}}$ & $1.94^{\mathrm{e}}$ & $1.76^{\mathrm{d}}$ \\
\hline 42 & $2.09^{\mathrm{c}}$ & $1.93^{b}$ & $1.90^{\mathrm{b}}$ & $1.89^{\mathrm{b}}$ & $1.71^{\mathrm{a}}$ & $2.55^{\mathrm{d}}$ & $2.36^{\mathrm{c}}$ \\
\hline 49 & $2.57^{\mathrm{c}}$ & $2.42^{\mathrm{b}}$ & $2.39^{\mathrm{b}}$ & $2.38^{\mathrm{b}}$ & $2.21^{\mathrm{a}}$ & $3.15^{\mathrm{d}}$ & $2.99^{c}$ \\
\hline 56 & $2.93^{c}$ & $2.78^{b}$ & $2.75^{\mathrm{b}}$ & $2.79^{\mathrm{b}}$ & $2.57^{\mathrm{a}}$ & $3.62^{\mathrm{d}}$ & $3.54^{\mathrm{cd}}$ \\
\hline \multicolumn{8}{|c|}{ Body weight gain } \\
\hline $7-19$ & $0.46^{\mathrm{e}}$ & $0.32^{\mathrm{d}}$ & $0.29^{c}$ & $0.24^{b}$ & $0.12^{\mathrm{a}}$ & $0.51^{\mathrm{e}}$ & $0.34^{\mathrm{d}}$ \\
\hline $20-56$ & $2.3^{\mathrm{a}}$ & $2.32^{\mathrm{a}}$ & $2.32^{\mathrm{a}}$ & $2.41^{\mathrm{b}}$ & $0.31^{\mathrm{a}}$ & $2.97^{\mathrm{a}}$ & $3.06^{\mathrm{b}}$ \\
\hline
\end{tabular}

\begin{tabular}{cccccccc}
\hline Age & & Male $^{1}$ & & Pooled & & \multicolumn{3}{c}{${\text { Analysis of } \text { Variance }^{3}}^{\text {(days) }}$} & $2 \times 1$ & $1 \times 1$ & $2 \times 2$ & & SE & & R & S & $\mathrm{R} \times \mathrm{S}$ \\
\hline
\end{tabular}

Body weight

\begin{tabular}{rlllllll}
7 & 0.14 & 0.14 & 0.14 & 0.002 & NS & NS & NS \\
14 & $0.31^{\mathrm{c}}$ & $0.29^{\mathrm{b}}$ & $0.22^{\mathrm{a}}$ & 0.003 & $<0.01$ & $<0.01$ & $<0.01$ \\
19 & $0.43^{\mathrm{c}}$ & $0.40^{\mathrm{b}}$ & $0.28^{\mathrm{a}}$ & 0.003 & $<0.01$ & $<0.01$ & $<0.01$ \\
21 & $0.57^{\mathrm{c}}$ & $0.50^{\mathrm{b}}$ & $0.42^{\mathrm{a}}$ & 0.006 & $<0.01$ & $<0.01$ & $<0.01$ \\
28 & $1.11^{\mathrm{c}}$ & $1.02^{\mathrm{b}}$ & $0.87^{\mathrm{a}}$ & 0.008 & $<0.01$ & $<0.01$ & $<0.01$ \\
35 & $1.69^{\mathrm{c}}$ & $1.59^{\mathrm{b}}$ & $1.43^{\mathrm{a}}$ & 0.009 & $<0.01$ & $<0.01$ & $<0.01$ \\
42 & $2.30^{\mathrm{c}}$ & $2.21^{\mathrm{b}}$ & $2.05^{\mathrm{a}}$ & 0.01 & $<0.01$ & $<0.01$ & $<0.01$ \\
49 & $2.93^{\mathrm{bc}}$ & $2.83^{\mathrm{b}}$ & $2.70^{\mathrm{a}}$ & 0.015 & $<0.01$ & $<0.01$ & $<0.01$ \\
56 & $3.49^{\mathrm{c}}$ & $3.35^{\mathrm{b}}$ & $3.25^{\mathrm{a}}$ & 0.017 & $<0.01$ & $<0.01$ & $<0.01$ \\
Body weight gain & & & & & & $<0.01$ \\
$7-19$ & $0.29^{\mathrm{c}}$ & $0.26^{\mathrm{b}}$ & $0.14^{\mathrm{a}}$ & 0.001 & $<0.01$ & $<0.01$ & $<0.01$ \\
$20-56$ & $3.06^{\mathrm{b}}$ & $2.95^{\mathrm{a}}$ & $2.97^{\mathrm{a}}$ & 0.003 & $<0.01$ & $<0.01$ & $<0.01$ \\
\hline
\end{tabular}

${ }^{1}$ Each treatment group was represented by one replicate floor pen. $3 \times 1=$ chicks were fed ad libitum for 3 days and then fasted for 1 day for 12 days (d 7 through d 19). Other groups were done in similar pattern.

${ }^{2}$ Values reported represent means for 48 chicks (d 7 through $\mathrm{d} 21$ ) or 40 chicks (d 22 through $d$ 56). Means within a row not followed by the same superscripts are significantly different.

${ }^{3}$ Probability of a significant treatment effect; $\mathrm{R}=$ restriction, $\mathrm{S}=\operatorname{sex}$ and $\mathrm{R} \times \mathrm{S}=$ interaction between $\mathrm{R}$ and $\mathrm{S}$.

their body weights. Consequently, body weights of the feed-skipped chicks were lower than those of ad libitum chicks at market age. No compensatory growth during refeeding was in agreement with observation of Washburn and Bondari (1978), Yu et al. (1990) and Pinchasov and Jensen
(1989), but in contrast to the results of Plavnik and Hurwitz (1985, 1988, 1990), McMurtry et al. (1988) and Santoso et al. (1993). Results of the previous study (Santoso et al., 1993) and present study showed that common feed restriction (the chick was fed certain degree of the control 


\section{SANTOSO ET AL.}

feed intake daily) and skip day feeding have different effect on broiler performance and body composition. Although feed intake degree of feed-skipped chicks (feed intake of feed-skipped chicks divided by feed intake of control chicks) during feed restriction period was higher in the present study, compensatory growth was not occurred. Jones and Farrell (1992) stated that the success of feed restriction was associated with the success in maintaining body weight stasis during period of feed restriction in proper period of feed restriction. Using skip day feeding, body weight was decreased by fasting and then was increased by repletion period (Pinchasov et al., 1985). However, period of feed restriction appear to influence the results. In the previous study, period of feed restriction was for 10 days, whereas in the present study, period of feed starvation was for 12 days. Jones and Farrell (1992) found that increasing the duration for 2 days decreased the ability of the broilers to achieve full body weight recovery. This finding suggests that factors influencing the occurrence of compensatory growth included the methods applied to the chicks and periods of feed restriction. The observation of Plavnik and Hurwitz (1985) and Wilson and Osborn (1960) also suggested that compensatory growth was obtained after short periods of feed restriction, whereas longer periods diminished recovery and might result in delay in achieving normal body weight or in a permanent stunting of animal.

During skip day feeding programs, female chicks consumed $650,527,484,375$ and $309 \mathrm{~g}$ for ad libitum, $3 \times 1,2 \times 1,1 \times 1$ and $2 \times$ 2 treatment group, respectively. Male chicks consumed 732, 573, 501, 398 and $320 \mathrm{~g}$ for ad libitum, $3 \times 1,2 \times 1,1 \times 1$ and $2 \times 2$ treatment group, respectively (table 2). The feedskipped female chicks consumed $81.1 \%, 74.5 \%$, $57.7 \%$ and $47.5 \%$ of ad libitum fed chicks for $3 \times 1,2 \times 1,1 \times 1$, and $2 \times 2$ treatment group, respectively. The feed-skipped male chickens consumed $78.3 \%, 68.4 \%, 54.4 \%$ and $43.7 \%$ of ad libitum fed chicks for $3 \times 1,2 \times 1,1 \times 1$ and $2 \times 2$ treatment group, respectively; Early skip day feeding programs reduced the consumption of the starter diets by $15 \%, 21 \%, 33 \%$ and $42 \%$ for $3 \times 1,2 \times 1,1 \times 1$ and $2 \times 2$ treatment group (females), and $7.5 \%, 45 \%, 32 \%$ and $51 \%$ for $3 \times 1,2 \times 1,1 \times 1$ and $2 \times 2$ treatment group (males) when compared with control. This should have an impact on production costs because the starter diets are generally the most expensive diet for broilers (Fontana et al., 1992).

After skip day feeding program ended, the feed-skipped chicks could not eat higher than those control chicks except for the $3 \times 1$ male chicks. Feed conversion ratio during the experiment period was better in the feed-skipped male chicks. The calculated improvement in feed conversion ratio was $2.2 \%$ and $2.7 \%$ for females in $1 \times$ 1 and $2 \times 2$ treatment group, respectively and $4.6 \%, 8.6 \%, 5.7 \%$ and $5.1 \%$ for males in $3 \times$ $1,2 \times 1,1 \times 1$ and $2 \times 2$ treatment group, respectively. Male chicks were more responsive to restriction in an early life in improving feed conversion ratio as noted by some investigators (for example, Santoso et al., 1993; Plavnik et al., 1986).

The factors regulating the concurrent growth rate of the restricted birds are related in part to plasma concentration of certain hormone related to growth rate; for example, plasma concentration of triiodothyronine $\left(\mathrm{T}_{3}\right)$ appear to be positively related to growth rate (Decuypere and Uyse, 1988; McGuinness and Cogburn, 1990). Newcombe et al. (1992) concluded that lower $\mathrm{T}_{3}$ than control chicks during recovery period may account for a lack of complete compensatory growth. Compensatory growth phenomenon in some groups was accompanied with hyperphagia and (the $3 \times 1$ male chicks) or lower feed conversion ratio. These results were in agreement with our previous results (Santoso et al., 1993). The factors regulating feed intake are related in part to the anatomical adaptation of the gastro-intestinal tract. e.g. its increase in weight and in digestive enzyme activity (Pinchasov et al., 1985). However, the anatomical adaptation of the gastro-intestinal tract might not be sufficient to allow the chick consume feed greater than control chicks in order to induce compensatory growth in the present study. Fjeld et al. (1989) suggested that protein might be a limiting nutrient during recovery period after a period of malnutrition. Plavnik and Hurwitz (1989) also suggested that essential amino acid requirements were higher in order to maximize growth in the first few weeks following feed restriction. If it is the case, the absence of compensatory growth 
EARLY SKIP DAY FEEDING AND GROWTH

TABLE 2. EFFECT OF EARLY SKIP DAY FEEDING ON FEED INTAKE, FEED CONVERSION RATIOS, AND LIVER WEIGHT

\begin{tabular}{|c|c|c|c|c|c|c|c|}
\hline \multirow{2}{*}{$\begin{array}{c}\text { Age } \\
\text { (days) }\end{array}$} & \multicolumn{5}{|c|}{ Female $^{1}$} & \multicolumn{2}{|c|}{ Male $^{1}$} \\
\hline & Control & $3 \times 1$ & $2 \times 1$ & $1 \times 1$ & $2 \times 2$ & Control & $3 \times 1$ \\
\hline \multicolumn{8}{|l|}{ Feed intake $(\mathrm{kg} / \mathrm{bird})$} \\
\hline $7-19$ days of age & 0.65 & 0.53 & 0.48 & 0.36 & 0.31 & 0.73 & 0.57 \\
\hline $20-56$ days of age & 4.52 & 4.36 & 4.34 & 4.40 & 4.08 & 5.20 & 5.62 \\
\hline $7-56$ days of age & 5.17 & 4.89 & 4.82 & 4.78 & 4.39 & 5.93 & 5.67 \\
\hline \multicolumn{8}{|c|}{ Feed conversion ratio (feed/gain) } \\
\hline 8-56 days of age & 1.86 & 1.86 & 1.86 & 1.82 & 1.81 & 1.75 & 1.67 \\
\hline \multicolumn{8}{|c|}{ Liver weight $(\mathrm{g} / 100 \mathrm{~g} \mathrm{BW})^{2}$} \\
\hline 56 days of age & 1.8 & 1.8 & 1.9 & 1.8 & 2.1 & 1.4 & 1.4 \\
\hline
\end{tabular}

\begin{tabular}{|c|c|c|c|c|c|c|c|}
\hline \multirow{2}{*}{$\begin{array}{c}\text { Age } \\
\text { (days) }\end{array}$} & \multicolumn{3}{|c|}{ Male $^{1}$} & \multirow{2}{*}{$\begin{array}{c}\text { Pooled } \\
\text { SE }\end{array}$} & \multicolumn{3}{|c|}{ Analysis of Variance $^{3}$} \\
\hline & $2 \times 1$ & $1 \times 1$ & $2 \times 2$ & & $\mathrm{R}$ & $\mathrm{S}$ & $\mathrm{R} \times \mathrm{S}$ \\
\hline
\end{tabular}

Feed intake $(\mathrm{kg} /$ bird $)$

$\begin{array}{rlll}7-19 \text { days of age } & 0.50 & 0.40 & 0.32 \\ 20-56 \text { days of age } & 4.85 & 4.90 & 4.66 \\ 7-56 \text { days of age } & 5.35 & 5.30 & 4.98\end{array}$

Feed conversion ratio (feed/gain)

8-56 days of age $\quad 1.60 \quad 1.65 \quad 1.66$

Liver weight $(\mathrm{g} / 100 \mathrm{~g} \mathrm{BW})^{2}$

56 days of age $\quad 1.6$

$\begin{array}{lll}1.6 & 1.5 & 1.5\end{array}$

$1.5 \quad 0.05$

NS

NS

NS

\footnotetext{
1 Each treatment group was represented by one replicate floor pen of 48 chicks (d 7 through d 19) or 40 chicks (d 20 through $\mathrm{d} 56$ ). $3 \times 1$ = chicks were fed ad libitum for 3 days and then fasted for 1 days for 12 days ( 7 through $d$ 19). Other groups were done in similar pattern.

${ }^{2}$ Values reported represent means for 8 chicks. Means within a row not followed by the same superscripts are significantly different.

${ }^{3}$ Probability of a significant treatment effect; $\mathrm{R}=$ restriction, $\mathrm{S}=\operatorname{sex}$ and $\mathrm{R} \times \mathrm{S}=$ interaction between $\mathrm{R}$ and $\mathrm{S}$.
}

and the limition of protein deposition during the recovery period is due to an inadequate supply of dietary protein as noted by Yu et al. (1990). Also, if it is the case, high protein diet during the first few weeks might overcome the problem of the absence of compensatory growth. Furthermore, high protein diet can be used to reduce body fat and abdominal fat weight (Fisher, 1984).

Effect of early skip day feeding on pen body weight and mortality are shown in table 3 . In the present study, mortality in males were lower in feed-skipped chicks. Some proposal were made to explain lower mortality in the restricted chicks. Bowes et al. (1988) and O'Sullivan et al. (1991) stated that the reduce in mortality rate was associated with a lower rate of mortality caused by Sudden Death Syndrome. Holloszy (1992) hypothesized that food restriction decreases mortality rate possible by decreased formation of toxins and/or carcinogens, and/or decreased accumulation of waste products. However, it is likely that longer period of starvation and more its severity decreased chick viability because of the crisis in nutrient intake leading to an impairment in metabolic processes.

Higher total pen weights were observed in the $3 \times 1$ or $2 \times 1$ group of male chickens in comparison with ad libitum group at 56 days of age. These results showed that although the 
individual body weights of the $3 \times 1$ or $2 \times 1$ groups were lower than those of control chicks, the total quantity of meat produced per pen was higher. These can be explained by the significant reductions in the rates of mortality observed in feed-skipped male chickens.

TABLE 3. EFFECTS OF EARLY SKIP DAY FEEDING ON WEIGHTS OF BODY, BODY PROTEIN AND BODY FAT AND MORTALITY IN EACH. PEN AT 56 DAYS OF AGE

\begin{tabular}{|c|c|c|c|c|c|}
\hline & & & Feeding & & \\
\hline & Control & $3 \times 1$ & $2 \times 1$ & $1 \times 1$ & $2 \times 2$ \\
\hline Body weig & & & & & \\
\hline Male & 119.6 & 131.1 & 125.5 & 117.4 & 110.5 \\
\hline Female & 108.3 & 105.5 & 104.6 & 105.8 & 97.6 \\
\hline Mortality & & & & & \\
\hline Male & 5 & 1 & 2 & 3 & 4 \\
\hline Female & 1 & 0 & 0 & 0 & 0 \\
\hline Body prot & & & & & \\
\hline Male & 19.4 & 20.8 & 20.2 & 19.1 & 17.3 \\
\hline Female & 17.2 & 15.6 & 16.0 & 16.8 & 15.2 \\
\hline Body fat & & & & & \\
\hline Male & 22.6 & 23.6 & 22.9 & 20.2 & 20.9 \\
\hline Female & 22.8 & 27.0 & 23.2 & 23.8 & 23.0 \\
\hline
\end{tabular}

The effect of early skip day feeding on carcass compositions and abdominal fat weight are shown in table 4. Body fat content of female chicks was increased in the $3 \times 1$ treatment group $(p<$ 0.05 ) or tended to be increased in other treatment groups, whereas moisture $(\mathrm{p}<0.05)$ and protein contents $(p<0.05)$ were decreased in $3 \times 1$ treatment group. Protein content of males was decreased, although it statistically was not significantly different. Abdominal fat pad weight of female chickens were significantly decreased $(\mathrm{p}<$ 0.05 ) in chicks fed the $2 \times 2$ treatment group. The abdominal fat weight of this group decreased by $18.0 \%$ compared with control group, however, that body weight also reduced by $12.2 \%$.

The effect of early skip day feeding on energy intake, carcass energy, energy loss and fat protein ratios of carcasses are shown in table 5 . The $3 \times 1$ treatment group in females had the lowest value of energy loss and highest value of fat protein ratio.
It is likely that protein synthesis of female chicks (especially the $3 \times 1$ group) was reduced, and or chicks used body protein for maintenance requirement during skip day feeding; and protein recovery during refeeding was not sufficient to achieve normal protein content. This finding was in agreement with the observation of Santoso et al. (1993) but in contrast with the observation of Plavnik and Hurwitz $(1985,1988)$. There was also sex dimorphism, especially for the $3 \times 1$ treatment group, in response to early skip day feeding on body composition. These results and our previous results (Santoso et al., 1993) also demonstrated that skip day feeding (the present study) and restriction-refeeding regimes (previous study) had different effect on body protein content of male chicks (skip day feeding reduced protein contents whereas restriction-refeeding program increased them) and body fat content of female chicks (skip day feeding increased body fat contents whereas restriction-refeeding regimens 


\section{EARLY SKIP DAY FEEDING AND GROWTH}

TABLE 4. EFFECT OF EARLY SKIP DAY FEEDING ON CARCASS COMPOSITION AND ABDOMINAL FAT WEIGHT OF BROILERS AT 56 DAYS OF AGE

\begin{tabular}{|c|c|c|c|c|c|c|c|}
\hline \multirow{2}{*}{$\begin{array}{c}\text { Age } \\
\text { (days) }\end{array}$} & \multicolumn{5}{|c|}{ Female $^{1}$} & \multicolumn{2}{|c|}{ Male $^{1}$} \\
\hline & Control & $3 \times 1$ & $2 \times 1$ & $1 \times 1$ & $2 \times 2$ & Control & $3 \times 1$ \\
\hline & & & & $\cdot(\%) \cdot$ & & & . \\
\hline Moistrue & $59.4^{2 \mathrm{c}}$ & $56.0^{\mathrm{a}}$ & $59.0^{\mathrm{bc}}$ & $58.0^{\mathrm{abc}}$ & $56.6^{b}$ & 60.9 & 61.8 \\
\hline Fat & $21.1^{\mathrm{a}}$ & $25.6^{\mathrm{b}}$ & $22.2^{\mathrm{ab}}$ & $22.5^{\mathrm{ab}}$ & $23.6^{\mathrm{ab}}$ & 18.9 & 18.0 \\
\hline Protein & $15.9^{b}$ & $14.7^{\mathrm{a}}$ & $15.3^{\mathrm{ab}}$ & $15.9^{\mathrm{b}}$ & $15.5^{\mathrm{b}}$ & 16.3 & 15.9 \\
\hline $\begin{array}{l}\text { Abdominal fat } \\
(\mathrm{g} / 100 \mathrm{~g} \mathrm{BW})^{2}\end{array}$ & $3.9^{\mathrm{b}}$ & $4.1^{\mathrm{b}}$ & $3.8^{\mathrm{b}}$ & $3.7^{\mathrm{ab}}$ & $3.2^{\mathrm{a}}$ & 3.0 & 2.6 \\
\hline
\end{tabular}

\begin{tabular}{|c|c|c|c|c|c|c|c|}
\hline \multirow{2}{*}{$\begin{array}{l}\text { Age } \\
\text { (days) }\end{array}$} & \multicolumn{3}{|c|}{ Male $^{1}$} & \multirow{2}{*}{$\begin{array}{c}\text { Pooled } \\
\text { SE }\end{array}$} & \multicolumn{3}{|c|}{ Analysis of Variance ${ }^{3}$} \\
\hline & $2 \times 1$ & $1 \times 1$ & $2 \times 2$ & & $\mathrm{R}$ & $\mathrm{S}$ & $\mathrm{R} \times \mathrm{S}$ \\
\hline & & & & (\%) & & & \\
\hline Moistrue & 61.1 & 62.2 & 61.1 & 0.3 & $<0.05$ & $<0.05$ & $<0.05$ \\
\hline Fat & 18.2 & 17.2 & 19.0 & 0.2 & $<0.05$ & $<0.01$ & NS \\
\hline Protein & 16.1 & 16.2 & 15.6 & 0.09 & $<0.05$ & $<0.01$ & NS \\
\hline $\begin{array}{l}\text { Abdominal fat } \\
(\mathrm{g} / 100 \mathrm{~g} \mathrm{BW})^{2}\end{array}$ & 3.0 & 2.7 & 2.7 & 0.09 & $<0.05$ & $<0.05$ & NS \\
\hline
\end{tabular}

${ }^{1}$ Each treatment group was represented by one replicate floor pen of 48 chicks (d 7 through d 19) or 40 chicks (d 20 through $\mathrm{d}$ 56). $3 \times 1=$ chicks were fed ad libitum for 3 days and then fasted for 1 days for 12 days (d 7 through $d$ 19). Other groups were done in similar pattern.

${ }^{2}$ Values reported represent means for 8 chicks. Means within a row not followed by the same superscripts are significantly different.

${ }^{3}$ Probability of a significant treatment effect; $R=$ restriction, $S=\operatorname{sex}$ and $R \times S=$ interaction between $R$ and $\mathrm{S}$.

reduced them). Rosebrough et al. (1986) also stated that total starvation resulted in an increase in body fat when refeeding occurs; in contrast, the restriction-refeeding regime resulted in a decrease in body fat during refeeding.

The effect of early skip day feeding on hepatic lipogenic enzyme activities and various lipid fraction contents in the liver are shown in table 6 and 7. At 21 or 56 days of age, none of early skip day feeding significantly affected hepatic acetyl-CoA carboxylase activities, whereas hepatic fatty acid synthetase activity at 21 days of age was significantly increased $(p<0.01)$, and at 56 days of age that activity was decreased in $1 \times 1$ treatment group. At 21 days of age, triglyceride content was increased $(p<0.01)$, however, at 56 days of age, that content was decreased. Phospholipid content was increased $(p<0.05)$ at 21 days of age, however, at 56 days of age, that content was not affected. At 21 days of age, free cholesterol contents were significantly in- creased ( $<<0.01)$, at 56 days of age, those contents were increased by $9.5 \%, 28.6 \%$ and $4.8 \%$ for the $2 \times 1,1 \times 1$ and $2 \times 2$ treatment group, respectively.

At 21 days of age, an increase in hepatic lipogenic enzyme activities might have contributed the raise of triglyceride content in the liver, Tanaka et al. (1975) found that lipogenesis was decreased by fasting, and then was increased by feed realimentation. If lipoprotein formation in the liver does not keep pace with the hepatic lipogenesis, triglyceride will be accumulated in the liver. At 56 days of age, triglyceride content was decreased. One of the factors responsible for decreasing triglyceride content in the liver might be increased transport of triglycerides from the liver into the blood. Griffin et al. (1982) stated that there is positive correlation between plasma triglyceride concentration and body fat. Furthermore, in the present study, there was negative relationship between triglyceride content in the 
TABLE 5. EFFECT OF EARLY SKIP DAY FEEDING ON ENERGY INTAKE (EI) CARCASS ENERGY (CE), ENERGY LOSS (EL), ENERGY EFFICIENCY (EE) AND FAT PROTEIN RATIOS (FPR) OF BROILERS AT 56 DAYS OF AGE

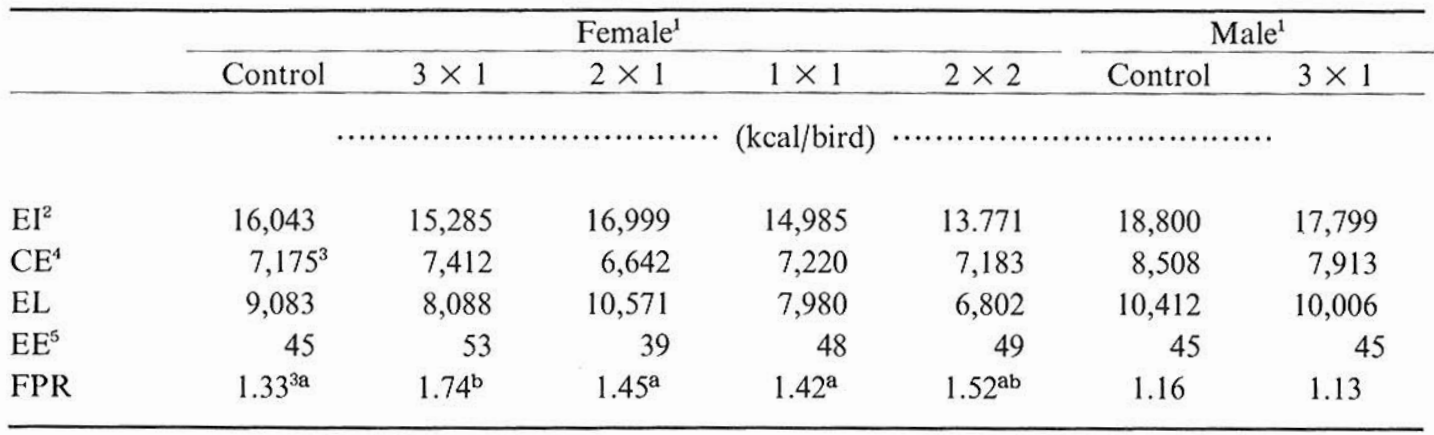

\begin{tabular}{|c|c|c|c|c|c|c|c|}
\hline & \multicolumn{3}{|c|}{ Male $^{1}$} & \multirow{2}{*}{$\begin{array}{c}\text { Pooled } \\
\text { SE }\end{array}$} & \multicolumn{3}{|c|}{ Analysis of Variance $^{6}$} \\
\hline & $2 \times 1$ & $1 \times 1$ & $2 \times 2$ & & $\mathrm{R}$ & $\mathrm{S}$ & $\mathrm{R} \times \mathrm{S}$ \\
\hline & & ............ & ............ & $\mathrm{kcal} / \mathrm{bird}$ & & $\ldots$ & \\
\hline $\mathrm{EI}^{2}$ & 17,604 & 16,735 & 15,856 & & & & \\
\hline $\mathrm{CE}^{4}$ & 7,922 & 7,255 & 7,494 & 238 & NS & NS & NS \\
\hline EL & 9,801 & 9,599 & 8,482 & & & & \\
\hline $\mathrm{EE}^{5}$ & 45 & 43 & 47 & & & & \\
\hline FPR & 1.13 & 1.06 & 1.21 & 0.03 & $<0.05$ & $<0.05$ & NS \\
\hline
\end{tabular}

1 Each treatment group was represented by one replicate floor pen of 48 chicks (d 7 through $\mathrm{d} 19$ ) or 40 chicks (d 20 through $\mathrm{d}$ 56). $3 \times 1=$ chicks were fed ad libitum for 3 days and then fasted for 1 day (d 7 through d 19). Other groups were done in similar pattern.

${ }^{2}$ Energy intake $=$ Feed intake $\times$ Metabolizable Energy of feed.

${ }^{3}$ Values reported represent means for 8 chicks. Means within a row not followed by the same superscripts are significantly different.

${ }^{4}$ Carcass Energy $=$ Fat weight of carcass $\times 9.129 \mathrm{kcal}+$ Protein weight of carcass $\times 5.5209$ kcal (Hakansson and Svensson, 1984).

${ }^{5}$ Energy efficiency $=$ Carcass Energy/Energy Intake $\times 100 \%$.

${ }^{6}$ Probability of a significant treatment effect; $\mathrm{R}=$ restriction, $\mathrm{S}=\operatorname{sex}$ and $\mathrm{R} \times \mathrm{S}=$ interaction between $\mathrm{R}$ and $\mathrm{S}$.

liver with total body fat $(\mathrm{r}=-0.74)$ as noted by Santoso et al. (1993). The chicken adipocyte has a limited capacity to synthesize fatty acid de novo (O'Hea and Leveille, 1969) and most of the fat deposited within the adipose tissue must be derived from the plasma (Griffin et al., 1982). Thus, triglyceride concentration in the liver and plasma might also contribute total body fat.

Fasting produces a clear decrease in chick liver HMG-CoA reductase activity, the rate-limiting enzyme of cholesterol biosynthesis (Ramirez et al., 1984). Changes in its activity correlate with changes in cholesterogenesis in response to different experimental conditions (Dietschy and Brown,
1974; Rodwell et al., 1976). Thus, an increase in cholesterogenesis in the liver during refeeding might partly explain the raise of hepatic cholesterol content.

The present results confirmed our previous results (Santoso et al., 1993) pertaining factors contributing body fat content. The response of chicks to early feed restriction might depend on the degree of feed restriction, the method of feed restriction, duration of feed restriction and sex. Early feed restriction could be used to reduce production cost because of the lower feed conversion ratio, mortality rate and the amount of starter diet consumed by broiler chicks. 
EARLY SKIP DAY FEEDING AND GROWTH

TABLE 6. EFFECT OF EARLY SKIP DAY FEEDING ON ACETYL-COA CARBOXYLASE (ACC) AND FATTY ACID SYNTHETASE (FAS) ACTIVITIES OF FEMALE BROILERS

\begin{tabular}{|c|c|c|c|c|c|c|c|}
\hline & \multicolumn{5}{|c|}{ Feeding ${ }^{1}$} & \multirow{2}{*}{$\begin{array}{c}\text { Pooled } \\
\text { SE }\end{array}$} & \multirow{2}{*}{ Prob $^{3}$} \\
\hline & Control & $3 \times 1$ & $2 \times 1$ & $1 \times 1$ & $2 \times 2$ & & \\
\hline & ............. & …....... & $\cdots(\mathrm{nm}$ & in $/ \mathrm{mg}$ & in $)^{4}$ & 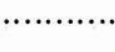 & ........... \\
\hline \multicolumn{6}{|c|}{ Acetyl-CoA carboxylase } & & \\
\hline 21 days of age & $1.3^{2}$ & 1.5 & 1.3 & 1.5 & 1.4 & 0.07 & NS \\
\hline 56 days of age & 0.7 & 0.6 & 0.6 & 0.7 & 0.6 & 0.04 & NS \\
\hline \multicolumn{8}{|l|}{ Fatty acid synthetase } \\
\hline 21 days of age & $3.7^{\mathrm{a}}$ & $4.6^{\mathrm{b}}$ & $4.7^{\mathrm{b}}$ & $5.2^{\mathrm{b}}$ & $5.4^{\mathrm{b}}$ & 0.12 & $<0.01$ \\
\hline 56 days of age & $2.3^{\mathrm{ab}}$ & $2.5^{\mathrm{b}}$ & $2.4^{\mathrm{b}}$ & $1.9^{\mathrm{a}}$ & $2.0^{\mathrm{a}}$ & 0.07 & $<0.05$ \\
\hline
\end{tabular}

$13 \times 1=$ chicks were fed ad libitum for 3 days and then fasted for 1 day for 12 days ( 7 through $d$ 19). Other groups were done in similar pattern.

${ }^{2}$ Values reported represent means for 8 chicks. Means within a row not followed by the same superscripts are significantly different.

${ }^{3}$ Probability of a significant treatment effect.

4 Enzymes activities are expressed as nanomole of substrate converted to product per minute per mg protein at $37^{\circ} \mathrm{C}$.

TABLE 7. EFFECTS OF EARLY SKIP DAY FEEDING ON VARIOUS LIPID FRACTIONS CONTENTS OF THE LIVER IN FEMALE BROILERS

\begin{tabular}{|c|c|c|c|c|c|c|c|}
\hline & \multicolumn{5}{|c|}{ Feeding ${ }^{1}$} & \multirow{2}{*}{$\begin{array}{c}\text { Pooled } \\
\text { SE }\end{array}$} & \multirow{2}{*}{ Prob $^{3}$} \\
\hline & Control & $3 \times 1$ & $2 \times 1$ & $1 \times 1$ & $2 \times 2$ & & \\
\hline \multirow{2}{*}{\multicolumn{8}{|c|}{21 days of age }} \\
\hline & & & & & & & \\
\hline Cholesterol ester & $0.8^{2}$ & 0.7 & 0.7 & 0.7 & 0.7 & 0.02 & NS \\
\hline Triglyceride & $23.2^{\mathrm{a}}$ & $23.9^{\mathrm{a}}$ & $22.9^{\mathrm{a}}$ & $32.9^{\mathrm{b}}$ & $38.7^{\mathrm{c}}$ & 0.5 & $<0.01$ \\
\hline Free cholesterol & $1.4^{\mathrm{a}}$ & $2.1^{\mathrm{b}}$ & $2.0^{\mathrm{b}}$ & $2.3^{\mathrm{b}}$ & $2.3^{\mathrm{b}}$ & 0.2 & $<0.01$ \\
\hline Phospholipid & $20.7^{\mathrm{a}}$ & $27.4^{\mathrm{b}}$ & $26.7^{\mathrm{b}}$ & $29.4^{\mathrm{b}}$ & $29.9^{\mathrm{b}}$ & 0.7 & $<0.05$ \\
\hline \multicolumn{8}{|l|}{56 days of age } \\
\hline Cholesterol ester & 0.7 & 0.7 & 0.7 & 0.6 & 0.7 & 0.02 & $\mathrm{NS}$ \\
\hline Triglyceride & $80.3^{c}$ & $21.1^{\mathrm{b}}$ & $25.9^{\mathrm{b}}$ & $29.3^{\mathrm{b}}$ & $16.1^{\mathrm{a}}$ & 1.60 & $<0.01$ \\
\hline Free cholesterol & 2.1 & 2.1 & 2.3 & 2.7 & 2.2 & 0.34 & NS \\
\hline Phospholipid & 27.7 & 27.8 & 29.7 & 28.0 & 29.3 & 0.7 & NS \\
\hline
\end{tabular}

$3 \times 1$ = chicks were fed ad libitum for 3 days and then fasted for 1 day for 12 days (d 7 through $\mathrm{d} 19)$. Other groups were done in similar pattern.

${ }^{2}$ Values reported represent means for 8 chicks. Means within a row not followed by the same superscripts are significantly different.

${ }^{3}$ Probability of a significant treatment effect.

\section{Literature Cited}

Association of official analytical chemists (AOAC). 1980. Official methods of analysis. 13ed. Association of official analytical chemists, Washington, DC.

Ballay, M., E. A. Dunnington, W. B. Gross and P. B. Siegel. 1992. Restricted feeding and broiler performance. Age at initiation and length of restriction. Poultry Sci. 30:440-447.

Bowes, V. A., N. J. Julian, S. Leeson and T. Stirtzinger. 1988. Effect of feed restriction on feed efficiency and incidence of sudden death syndrome in broiler chickens. Poultry Sci. 67:1102-1104.

Decuypere, E. and J. Buyse. 1988. Thyroid hormones, corticosterone, growth hormone and somatomedins 
in avian species: general effects and possible implications in fattening, in: Leclercq, B. and C. C. Whitehead (Eds), Leanness in Domestic Birds. Genetic, metabolic and hormonal aspects, pp. 295312 (London, Butterworths).

Dietschy, J. M. and M. S. Brown. 1974. Effects of alterations of the specific activity on the intracellular acetyl $\mathrm{CoA}$ pool on apparent rates of hepatic cholesterogenesis. J. Lipid Res. 15:508.

Duncan, D. B. 1955. Multiple range and multiple F test. Biometrics, 11:1-42.

Fisher, C. 1984. Fat deposition in broilers, in Wiseman, J (Eds), Fats in animal nutrition, pp. 437-470 (London, Butterworths).

Fjeld, C. R., D. A. Schoeller and K. H. Brown. 1989. Body composition of children recovering from severe protein-energy malnutrition at two rates of cath-up growth. Am. J. Clin. Nutr. 50:1266-1275.

Fontana, E. A., W. D. Weaver, Jr., B. A. Watkins and D. M. Denbow. 1992. Effect of early feed restriction on growth, feed conversion, and mortality in broiler chickens. Poultry Sci. 71:1296-1305.

Griffin, H. D., C. C. Whitehead and L. A. Broadbent. 1982. The relationship between plasma triglyceride concentration and body fat content in male and female broilers - a basis for selection? Bri. Poultry Sci. 23:15-23.

Hakansson, J. and S. A. Svensson. 1984. Gross energy content of fat and protein in different tissues of male broiler chicks. Swed. J. Agric. Res. 14:207212 .

Holloszy, J. O. 1992. Exercise and food restriction in rats. J. Nutr. 122:774-777.

Hsu, R. Y., G. Wasson and J. W. Porter. 1965. The purification and properties of the fatty acid synthetase of pigeon liver. J. Biol. Chem. 240: 3736-3746.

Jones, G. P. D. and D. J. Farrell. 1992. Early-life food restriction of broiler chickens. II. Effects of food restrictions on the development of fat tissue. Bri. Poultry Sci. 33:589-601.

Lowry, O. H., N. J. Rosebrough, A. L. Fart and R. J. Randell. 1951. Protein measurement with the folin phenol reagent. J. Biol. Chem. 193:265-275.

McGuiness, M. C. and L. A. Cogburn. 1990. Measurement of developmental changes in plasma insulin-like growth factor-I levels of broiler chickens by radioreceptor assay and radioimmunoassay. General and Comparative Endocrinology. 79:446458.

McMurtry, J. P., R. W. Rosebrough, I. Plavnik and H. L. Carwright. 1988. Influence of early plane of nutrition on enzyme systems and subsequent tissue deposition, in: G. L. Steffens and T. S. Rumsey (Eds). Biomechanism, regulating, growth and development, pp. 329-341 (Dordrecht, Kluwer Academic Publications).

Newcombe, M., A. L. Cartwright, J. M. Harter-Dennis and J. P. McMurtry. 1992. The effect of increasing photoperiod and food restriction in sexed, broiler- type birds. II. Plasma thyroxine, triiodothyronine, insulin-like growth factor-I and Insulin. Bri. Poultry Sci. 33:427-436.

O'Hea, E. K. and G. A. Leveille. 1969. Lipid biosynthesis and transport in the domestic chick (Gallus domesticus). Comp. Biochem. Physiol. 30:149-159.

O'Sullivan, N. P., E. A. Dunnington and P. B. Siegel. 1991. Growth and carcass characteristics of earlyand late-feathering broilers reared under different feeding regimens. Poultry Sci. 70:1323-1332.

Pinchasov, Y. and L. S. Jensen. 1989. Comparison of physical and chemical means of feed restriction in broiler chicks. Poultry Sci. 68:61-69.

Pinchasov, Y., I. Nir and Z. Nitsan. 1985. Metabolic and anatomical adaptation of heavy-bodied chicks to intermittent feeding. 1. Food intake, growth rate, organ weight, and body composition. Poultry Sci. 64:2098-2109.

Plavnik, I. and S. Hurwitz. 1985. The performance of broiler chicks during and following a servere feed restriction at on early age. Poultry Sci. 64:348355.

Plavnik, I. and S. Hurwitz. 1988. Early feed restriction in chicks: effect of age, duration, and sex. Poultry Sci. 67:384-390.

Plavnik, I. and S. Hurwitz. 1989. Effect of dietary protein, energy and feed pelleting on the response of chicks to early feed restriction.

Plavnik, I. and S. Hurwitz. 1990. Performance of broiler chickens and turkey poults subjected to feed restriction, or to feeding of low sodium diets at an early age. Poultry Sci. 69:945-952.

Plavnik, I. and S. Hurwitz. 1991. Response of broiler chickens and turkey poults to food restriction of varied serverity during early life. Bri. Poultry Sci. 32:343-352.

Plavnik, I., I. P. McMurtry and R. W. Rosebrough. 1986. Effects of early feed restriction in broilers. I. Growth and carcass composition. Growth. 50: 68-76.

Qureshi, A. A., W. C. Burger, N. Prentice, H. R. Bird and M. L. Sunde. 1980. Regulation of lipid metabolism in chicken liver by dietary cereals. J. Nutr. 110:388-393.

Ramirez, H., M. J. Alejandre, M. F. Zafra, J. L. Segovia and E. Garcia-Peregrin. 1984. Effect of fasting on 3-hydroxy-3-methylglutaryl-CoA reductase and microsomal lipid composition. Nutr. Int. Rep. 30:720-734.

Rodwell, V. W., J. L. Nordstrom and J. J. Mitschelen. 1976. Regulation of HMG-CoA reductase. Adv. Lipid Res. 14:1.

Rosebrough, R. W., N. C. Steele, J. P. McMurtry and I. Plavnik. 1986. Effect of early feed restriction in broilers. II. Lipid metabolism. Growth. 50:217227.

Santoso, U., K. Tanaka, S. Ohtani and Y. B. Sun. 1993. Effects of early feed restriction on broiler performances and body composition. AJAS 6(3): 401-410. 


\section{EARLY SKIP DAY FEEDING AND GROWTH}

Tanaka, K., K. Kitahara and K. Shigeno. 1979. Effects of dietary protein level on lipid metabolism. J. Zootechn. Sci. 50:44-54.

Tanaka, K., T. Sen and K. Shigeno. 1975. The effect of fasting and refeeding on lipids of serum and liver in the meat-type chicken. J. Zootechn. Sci. 46:396-402.

Washburn, K. W. and K. Bondari. 1978. Effects of timing and duration of restricted feeding on compensatory growth in broilers. Poultry Sci. 57:10131021 .
Wilson, P. N. and D. F. Osbron. 1960. Compensatory growth after undernutrition in mammals and birds. Biol. Rev. 325-363.

Yoshida, M. 1975. Design of experiments for animal husbandry. pp. 126-143. Youkendo Press, Tokyo, Japan.

$\mathrm{Yu}$, M. W., F. E. Robinson, M. T. Clandinin and L. Bodnar. 1990. Growth and body composition of broiler chickens in response to different regimes of feed restriction. Poultry Sci. 69:2074-2081. 